largely of mica-schists and clay-slates. In another memoir just published he furnishes additional information regarding the succession of these rocks. The old or fundamental (Archæan) rocks composed of gneiss, granite, \&c., are overlain by thick masses of reddish sandstones, followed by quartzites and limestones, over which come Augen-gneiss, hornblende-schist, mica-schist, \&c. This order of sequence, which is shown in numerous natural sections, will be at once recognised as that which Murchison first showed to be the stratigraphical succession in the north-west of Scotland. It is interesting to find that the parallelism which was traced many years ago between the structure of the Highlands of Scotland and the uplands of Scandinavia continues to be confirmed by the more detailed surveys of recent years.

\section{OBSERVATION OF THE GREAT COMET OF 1882}

(Communicated by Vice-Admiral Rowan, Superintendent U.S. Naval Observatory)

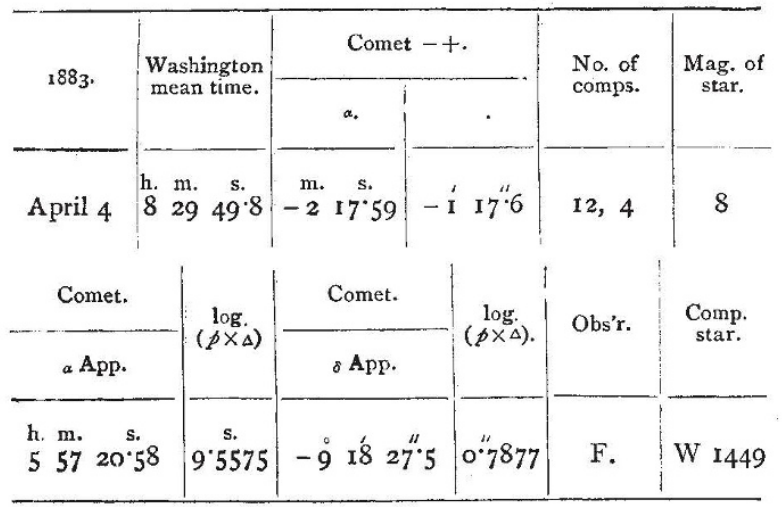

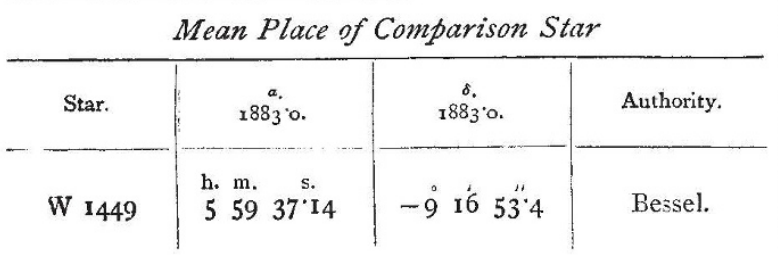

\begin{tabular}{|c|c|c|c|}
\hline \multirow{2}{*}{ Date. } & Obs. & Comp. & \multirow{2}{*}{ Eph. } \\
\hline & $\Delta a$. & $\Delta_{\delta}$. & \\
\hline I 825. & $\begin{array}{c}s . \\
+4.06\end{array}$ & $+I_{4}^{\prime \prime}$ & $\begin{array}{l}\text { NatURE, vol. xxvii. p. } 226, \\
\text { and } A \text { st. Reg. No. } 243, \text { p. } 72 .\end{array}$ \\
\hline
\end{tabular}

This observation was made with the 26 -inch equatorial, and compared with the following of three bright points in the nucleus. If we had compared the middle point of the nucleus with the comet, the corrections would have been $\quad \Delta a=+\mathrm{I}^{\mathrm{s} \cdot 3} \quad \Delta \delta=+\mathrm{o}^{\prime} \cdot 3$.

E. FRISBY,

Washington, April $6 \quad$ Prof. Math., U.S.N.

\section{ANTHROPOLOG $Y^{1}$}

I.

THE invitation to lecture on anthropology with which I have been honoured gives me freedom to speak both of the races of mankind zoologically, and also of the thoughts, arts, and habits which form their civilisation.

I Two lectures on "Anthropology," delivered on February $\mathrm{r}_{5}$ and $2 \mathrm{I}$ at the University Museum, Oxford, by E. B. Tylor, D.C.L., F.R.S.
It is on the development of civilisation that I especially wish to dwell, a subject of direct interest always and to all, and the more opportune now that the practical question of the instalment of a Museum of Civilisation in Oxford is under discussion. Still, man's bodily and mental history so act and interact on each other that it is well to carry on their study together. Both depend on the great principle of adaptive change, where rise in organisation gives fuller and freer existence, till "correspondence with the énvironment" fixes a more or less permanent state, or suppression or disuse brings on degeneration. These are processes systematised in the theories of development or evolution which have of late years become predominant, and which seek to account for the change of plants and animals on the earth by modified descent, and of mental and moral phenomena by modified sequence. There is a consideration I wish to bring prominently forward, as not having had the attention it deserves. It is that these processes of development, or evolution, or transformism were long ago recognised to no small extent by ethnologists. Thus Prichard, the leader of the monogenist school forty years ago, brought forward evidence for the derivation of the races of mankind from one original ancestral pair, whom he considered to have been negroes, whose descendants more or less varying by the operation of natural causes became modified or transformed into the various races adapted for life in the various climates of the earth. But this, so far as it goes, is the very theory of development or modified descent. Any ethnologist who argues on natural grounds "that all the races of man are descended from a single primitive stock," is an evolutionist within these limits; in fact these words are quoted not from Prichard or Quatrefages, but from Darwin. Within the last generation the science of man has had new evidence and argument brought within its range. The discovery that men were already making rude flint implements in the Quaternary period, when the contours of hill and valley were quite other than during the few thousand years known to chronology, has made a new scientific departure, placing primæval man in the hands of the geologists, who are now discussing whether he even existed in the yet more vastly remote Tertiary period. A yet greater move has been made by Darwin's systematic application of the principles of variation of breeds or races to account for the transitions between species or genera. How these have become transformed in the course of geological time is seen in Huxley's plate of the bones of the four-toed Orohippus, followed by the three-toed Miohippus and Hipparion, and this again by the horse of the present day. Zoologists thus enabled to reconstruct ideally the ancestry of the horse, are hopeful some day to discover likewise the fossil pedigree of the rider.

Thus it is plain why the new lines of biological research, whether into the general causes of variation in animals, or into the origin of the human species from a succession of lower mammalian forms, have not checked but stimulated the research which relates to man as man. Anthropologists do not feel as if their science had been plucked up by the roots and planted somewhere else; it is growing where it was, only cultivated higher than in old times. What substantial progress has been made of late years is well seen in the difficult department of craniology. That there really is something in the shape of a skull will be admitted when one compares the two before us on the table, types which illustrate an interesting point in the early history of our own country. The narrower skull belonged to one of that dolichocephalic Stone Age population whose remains were buried in the long-barrows on our downs. The broader skull belonged to one of the brachycephalic men of the later round-barrows. In the work of Greenwell and Rolleston will be found the anatomical comparison of these skull-types, and the evidence that the earlier tribes were not exterminated by the later 